\title{
Oestrogen receptor $\beta$ and neoadjuvant therapy with tamoxifen: prediction of response and effects of treatment
}

\author{
WR Miller', TJ Anderson', JM Dixon' and PTK Saunders*,2 \\ 'Breast Unit Research Group, University of Edinburgh, Western General Hospital, Edinburgh EH4 2XU, UK; ${ }^{2}$ MRC Human Reproductive Sciences Unit, \\ Centre for Reproductive Biology, 49 Little France Crescent, Edinburgh EHI6 4SB, UK
}

In order to elucidate the relative importance of oestrogen receptor (ER) $\alpha$, ER $\beta$ and an $E R \beta$ variant $(E R \beta 2 / \beta c x)$ in the response of breast cancers to tamoxifen, tumour levels of each receptor were assessed in 36 patients before and after 3 months of neoadjuvant treatment with tamoxifen ( $20 \mathrm{mg}$ daily). All patients were postmenopausal women presenting with large ER $\alpha$-positive breast cancers. Clinical response to treatment was assessed by tumour volume changes as determined from sequential ultrasounds and pathological response by comparison of the tumour morphology before and after treatment. Of 33 cases, 23 (70\%) were classified as having a clinical response and 16 (48\%) as having a response pathologically. All tumours stained positively for ER $\alpha$ and $\operatorname{ER} \beta$ and I 5 out of 33 (45\%) for $E R \beta 2 / \beta c x$. There were no significant differences in quantitative expression of any receptor between tumours that subsequently responded and that did not, whether response was assessed clinically or pathologically. Tamoxifen treatment was associated with a decrease in $\mathrm{ER} \alpha$, but an increase was the most frequent change (I7 out of 33) in ER $\beta$, and no consistent change was evident in staining of the $E R \beta 2 / \beta c x$ variant. In summary, $E R \beta \mid$ and $E R \beta 2 / \beta c x$ variant protein are detected in $E R \alpha$-positive breast tumours but their expression is not associated with a response to tamoxifen. Differential changes in $E R \alpha$ and $E R \beta$ were seen with treatment.

British Journal of Cancer (2006) 94, 1333-1338. doi:10.1038/sj.bjc.6603082 www.bjcancer.com

Published online 18 April 2006

(c) 2006 Cancer Research UK

Keywords: breast; oestrogen receptor; $\mathrm{ER} \beta$ varient

The anti-oestrogen tamoxifen has a central place in the treatment of breast cancer. However, many tumours appear refractory to the drug and there is a need to discover predictive markers that can accurately identify hormone responsive tumours. In this setting, oestrogen receptor (ER) $\alpha$ is the single most informative marker, receptor-negative tumours rarely benefiting from endocrine therapy (Miller, 1996). However, although responses are largely restricted to $\mathrm{ER} \alpha$-positive tumours, only between 60 and $70 \%$ of these cancers shrink with treatment. Hence, there is a requirement for additional markers to improve discrimination. Interest in the role played by receptors for oestrogen in breast cancer was revitalised by the discovery of a second form of oestrogen receptor, now named ER $\beta$ (Kuiper et al, 1996; Mosselman et al, 1996). In particular, it is notable that cell-based studies have suggested that coexpression of $\operatorname{ER} \beta$ in ER $\alpha$-positive cells may modulate the ability of the cells to respond to oestrogens (Hall and McDonnell, 1999; Strom et al, 2004) and studies using mice with targeted disruption of the $\operatorname{ER} \beta$ gene have endorsed this idea (Weihua et al, 2000; Lindberg et al, 2003). In the light of these observations, the suggestion has been made that the level of expression of ER $\beta$ in ER $\alpha$-positive breast cancers might modify tumour response to anti-oestrogenic action. This could account for resistance to endocrine therapy but it remains a topic of debate (reviewed by

*Correspondence: Professor PTK Saunders; E-mail: p.saunders@ed.ac.uk Received 25 August 2005; revised 8 February 2006; accepted 27 February 2006; published online 18 April 2006
Warner et al, 2000; Speirs et al, 2004). The situation is complicated further by the identification of a number of splice variant isoforms of the human $\operatorname{ER} \beta$ gene (Moore et al, 1998), the mRNAs for which have been detected in breast cancer tissues and breast cancer cell lines (Fuqua et al, 1999; Speirs et al, 2000; Poola et al, 2002a,b). Studies in vitro have suggested that $\operatorname{ER} \beta$ isoforms with deletions of selected exons, or with alternative splicing at the C-terminus, may act as dominant-negative inhibitors of full-length $\mathrm{ER} \alpha$ and/or $\mathrm{ER} \beta$ (Ogawa et al, 1998b; Inoue et al, 2000; Peng et al, 2003).

An antibody specific for full-length $\operatorname{ER} \beta$, hereafter referred to as $\mathrm{ER} \beta 1$, has been used previously to delineate the pattern of expression of this isoform of the receptor in breast cancer biopsies (Saunders et al, 2002b; Carder et al, 2005). The present paper has taken advantage of the development of a monoclonal specific for the $\mathrm{ER} \beta \mathrm{cx} / \beta 2$ splice variant (Saunders et al, 2002a) to determine whether expression of this isoform influences response to antioestrogen therapy as has been claimed by others (Saji et al, 2002a, b).

\section{MATERIALS AND METHODS}

\section{Patients}

All patients were referred between 1992 and 1995 to the Edinburgh Breast Unit and had histologically confirmed diagnosis of breast cancer (Miller et al, 1999). The women were postmenopausal, aged between 56 and 80 years, had a large $(>3 \mathrm{~cm})$ primary tumour 
with an ER histoscore $>80$ (equivalent to $\geqslant 5$ Allred score although a single case was subsequently graded as score 4 by the research lab) or a biochemical score of $>20 \mathrm{fmol} \mathrm{mg} \mathrm{protein}^{-1}$ (on the initial biopsy taken for diagnosis) and had no evidence of distant metastatic disease. None had received prior treatment with hormonal agents for breast cancer or were taking hormone preparations at the time of study. Tumour size was monitored clinically (by calipers) and by breast ultrasound before and at monthly intervals during treatment. Therapy comprised daily administration of tamoxifen $(25 \mathrm{mg})$ for 3 months; four patients electively continued on therapy for a further 3 months. A total of 72 consecutive patients were entered into the study; however, data are presented in 33 for $\mathrm{ER} \alpha$ and $\mathrm{ER} \beta 1$ and the $\mathrm{ER} \beta 2 / \beta \mathrm{cx}$ variant because in the remainder either pre- and/or post-treatment tumour blocks were exhausted by use for other studies. The demographics of the investigated cases were not different from the recruited population. The studies were performed with the patients' informed consent and ethical permission (LREC nos. $2001 / 8 / 80$ and $2001 / 8 / 81$ )

\section{Clinical response}

Clinical response was usually based on change in tumour volume between pretreatment and 3-month values; however, assessment was made at 6 months in those patients electing for extended treatment. Ultrasound measurement of three orthogonal tumour diameters produced an estimate of tumour volume. Reduction in tumour volumes $>25 \%$ was regarded as evidence of tumour response; those $>50 \%$ were categorised as major response (Forouhi et al, 1994).

\section{Pathological response}

Histological sections from the initial biopsy and the final surgical excision were assessed for decrease in cancer cellularity and increase in fibrosis gland formation. Where this occurred, the tumour was classified as having a pathological response, and where clear changes in cellularity and/or fibrosis were not apparent, the tumour was graded as no pathological response.

\section{Tumour}

Samples of each breast cancer was obtained by biopsy (before treatment) and by definite surgery (wide local excision or mastectomy) after treatment. Tumours were fixed in $10 \%$ neutral buffered formaldehyde for $16-24 \mathrm{~h}$, then stored in $70 \%\left(\mathrm{wv}^{-1}\right)$ ethanol before processing into paraffin wax at the Department of Pathology using standard procedures.

\section{Antibodies}

The anti-hER $\alpha$ mouse monoclonal antibody (code 1D5) was obtained from Dako (Cambridge, UK). Monoclonal antibodies specific for C-terminal peptides within wild-type human $\operatorname{ER} \beta$ (hER $\beta 1$, wild type; accession AB006590; Ogawa et al, 1998a; Serotec UK MCA1974S) as well as one of the variant isoforms of hER $\beta$ known as hER $\beta 2 / \beta \mathrm{cx}$ (accession AB006589; Moore et al, 1998; Ogawa et al, 1998b; Serotec UK, MCA 2279S) were prepared using standard methods as described previously (Saunders et al, $2000,2002 a)$. Specificity for the $\operatorname{ER} \beta$ isotype to which they were directed has been confirmed on Western blots using recombinant proteins (see Figure 2 in Saunders et al, 2002a). Neither antibody showed any crossreactivity against ER $\alpha$ (Saunders et al, 2002a). These antibodies have been used previously to determine the patterns of expression of ER $\beta 1$ in cancers of the breast (Saunders et al, 2002b; Carder et al, 2005) and prostate (Torlakovic et al, 2002) as well as in a variety of non-malignant adult tissues
(Saunders et al, 2000, 2002a; Critchley et al, 2002; Gaskell et al, 2003).

\section{Immunohistochemistry}

Sections $(4 \mu \mathrm{m})$ were mounted on Superfrost coated slides (BDH, Poole, Dorset, UK), dewaxed and rehydrated in gradient alcohols and distilled water before staining with specific antibodies as outlined below.

Anti-ER $\alpha \quad$ All staining for ER $\alpha$ was carried out in the Pathology Department of the Western General Hospital. An endogenous biotin block was carried out by applying $100 \mu \mathrm{l}$ egg white blocking solution for $30 \mathrm{~min}$. Anti-ER $\alpha$ Dako was diluted 1 in 50 in biotin diluent for primary antibodies (PBS, goat serum and d-biotin), and applied to the sections for $60 \mathrm{~min}$ at room temperature. The secondary antibody, biotinylated anti-mouse Ig (Vector Laboratories, Peterborough, Cambridgeshire, UK) was diluted $1: 2000$ in 'background reducing diluent' (Dako) and applied to the sections for $30 \mathrm{~min}$ at room temperature. The tertiary system (ABC-HRP, Dako) was applied as per the manufacturer's instructions for $30 \mathrm{~min}$ at room temperature. The tissue was visualised by immersing sections in $3,3^{\prime}$-diaminobenzidine tetrahydrochloride (DAB) for $5 \mathrm{~min}$. Sections were counterstained using Mayers haematoxylin (Sigma-Aldrich, Poole, Dorset, UK), dehydrated through gradient alcohols and mounted.

Anti-ER $\beta$ Tissue sections were dewaxed in Histoclear (National Diagnostics, Atlanta, GA, USA) and rehydrated in descending grades of alcohol to $\mathrm{dH}_{2} \mathrm{O}$. Antigen retrieval was carried out by pressure cooking in $0.05 \mathrm{M}$ glycine $0.01 \%$ EDTA pH 3.5 for $3 \mathrm{~min}$ setting 2 (Tefal, Nottingham, UK) and sections left to stand undisturbed for $20 \mathrm{~min}$. Sections were blocked for $30 \mathrm{~min}$ in normal rabbit serum (NRS; Diagnostics Scotland, Edinburgh, Scotland, UK) diluted 1:4 in TBS containing 5\% BSA (NRS/TBS/ BSA), rinsed briefly in TBS and an avidin-biotin block performed using reagents from Vector (Petersborough, UK). Anti-ER $\beta$ antibodies were diluted in NRS/TBS (ER $\beta 1,1$ in $20 ; \operatorname{ER} \beta \operatorname{cx} / \beta 21$ in 40) and incubated on sections overnight at $4^{\circ} \mathrm{C}$. Sections were washed twice for $5 \mathrm{~min}$ each in TBS and incubated with biotinylated rabbit anti-mouse immunoglobulin (Dako) diluted $1: 500$ in NRS/TBS/BSA. Bound antibodies were visualised by incubation with DAB (liquid DAB cat K3468, Dako); the DAB was added to sections at $8 \mathrm{~s}$ intervals and the colour allowed to develop for exactly $3 \mathrm{~min}(\mathrm{ER} \beta 1)$ or $5 \mathrm{~min}(\mathrm{ER} \beta 2 / \beta \mathrm{cx})$. Control sections previously used to determine the dilutions of antibodies were included in all experimental runs. Sections were counterstained with haematoxylin.

Images were captured using an Olympus Provis microscope (Olympus Optical Co, London, UK) equipped with a Kodak DCS330 camera (Eastman Kodak Co, Rochester, NY, USA).

\section{Quantitation of immunohistochemical staining}

Quantitation was based on a scoring system reported in detail previously (Allred et al, 1998; Leake et al, 2000). This method is based on a composite additive score of intensity $0-3$ and the proportion of malignant epithelial cells staining $0-5$. This gives a range of $0-8$ for each tissue. Statistical analysis was carried out using the Wilcoxon matched-pairs signed-ranks test, as this is more sensitive than the Student's $t$-test for small numbers of samples.

\section{RESULTS}

\section{Response}

Of the 33 patients studied, $23(70 \%)$ were classified as having a clinical response and $16(48 \%)$ as having a response in tumour 
pathology. Although the majority of clinical responders/nonresponders had corresponding changes in tumour pathology, one tumour that did not change in tumour volume with treatment showed significant changes in tumour morphology; conversely, eight tumours shrinking clinically with treatment did not change their morphological appearance.

\section{Oestrogen receptor $\alpha$}

All patients were required to have $\mathrm{ER} \alpha$-positive tumour in order to be eligible for the study. There was no quantitative difference in the initial staining score of tumours that either responded or did not, clinically or morphologically (data not shown). Median (range) was $7(6-8)$ for responding tumours and 7 (4-8) for non-responders (Table 1A).

Comparison of biopsies taken before and during treatment with tamoxifen showed that ER $\alpha$ category scores decreased in all but six tumours (five tumours were unchanged and one increased). Although only one score fell to 0 , the difference between preand treated tumour was highly significant $(P<0.0001$ by paired Wilcoxon test). No significant differences in change of score were apparent between tumours that responded and that did not, whether response was assessed clinically or by morphology (Table 1).

\section{Oestrogen receptor $\beta 1$}

All tumours stained positively with scores ranging from 5 to 8 . Although the median value was similar in cancers responding and not responding clinically (median 7 , range 5-8 in responding tumours, and median 7 , range $6-8$ in non-responding cancers) because of the difference in the distribution of values, levels were significantly higher in non-responding tumours $(P=0.03$ by paired Wilcoxon test). The levels of ER $\beta 1$ were not significantly different in tumours that morphologically changed with treatment as compared with those that did not. There was no correlation between $\operatorname{ER} \beta 1$ and $E R \alpha$ scores and expressing results as the ratio of $\mathrm{ER} \alpha$ to $\mathrm{ER} \beta 1$ failed to increase discrimination between responding and non-responding tumours (Table 2).

In contrast to $\mathrm{ER} \alpha$, tamoxifen treatment tended to be associated with an increase in the staining intensity of $\operatorname{ER} \beta 1$, with 17 of 33 having a higher staining score after treatment. This difference in the staining pattern of ER $\beta 1$ with treatment is significantly different from that observed in $\operatorname{ER} \alpha(P=0.001)$. However, the pattern of change in the ER $\beta 1$ score with treatment did not differ

Table I Oestrogen receptor $\alpha$

(A) Immunohistochemical score in tumours responding (Resp) and not responding (Non-R) to tamoxifen ${ }^{\mathrm{a}}$

\begin{tabular}{lccrc} 
Score & $\mathbf{4}$ & $\mathbf{6}$ & $\mathbf{7}$ & $\mathbf{8}$ \\
\hline Total & 1 & 2 & 17 & 13 \\
Resp (Clin) & & $\mid$ & 13 & 9 \\
Non-R (Clin) & 1 & $\mid$ & 4 & 4 \\
Resp (Path) & & $\mid$ & 10 & 5 \\
Non-R (Path) & 1 & $\mid$ & 7 & 8
\end{tabular}

(B) Change in immunohistochemical score with tamoxifen treatment $^{\mathrm{a}}$

\begin{tabular}{lccc} 
& Decrease & No change & Increase \\
\hline Total & 27 & 5 & 1 \\
Clin Resp & 18 & 4 & 1 \\
Clin Non-R & 9 & 1 & 0 \\
Path Resp & 12 & 3 & 1 \\
Path Non-R & 15 & 2 & 0 \\
\hline
\end{tabular}

${ }^{a}$ No significant differences between responding and non-responding tumours. according to response, whether this was assessed clinically or by tumour pathology.

\section{Oestrogen receptor $\beta 2 / \beta \mathrm{cx}$ splice variant}

Expression of the ER $\beta 2 / \beta \mathrm{cx}$ variant was detected by immunohistochemistry in 15 of 33 tumours (45\%). Before therapy, the level of expression of $\mathrm{ER} \beta 2 / \beta \mathrm{cx}$ did not relate to expression of $\mathrm{ER} \alpha$ or ER $\beta 1$, and examples of divergent results are shown in Figure 1. Note that as ER $\beta 1$ immunoexpression was found in all tumours, $55 \%$ were $\operatorname{ER} \beta 1$ positive/ER $\beta 2 / \beta \mathrm{cx}$ negative. There was no difference in the status/level of expression of $\mathrm{ER} \beta 2 / \beta \mathrm{cx}$ variant between tumours responding to and those that did not to tamoxifen (Table 3). Expressing results as a ratio with $\mathrm{ER} \alpha$ or $\operatorname{ER} \beta 1$ failed to increase discrimination between responding and non-responding tumours (results not shown).

Treatment with tamoxifen resulted in decreased expression of $\mathrm{ER} \beta 2 / \beta \mathrm{cx}$ in 11 cases, increased expression in six tumours and no changes in 16. Changes in expression were not related to response or to changes in $\operatorname{ER} \alpha$ and $\operatorname{ER} \beta 1$ (Figure 2).

Table 2 Oestrogen receptor $\beta$ । (wild type)

(A) Immunohistochemical score in tumours responding (Resp) and not responding (Non-R) to tamoxifen ${ }^{\mathrm{a}}$

\begin{tabular}{lllll} 
Score & $\mathbf{5}$ & $\mathbf{6}$ & $\mathbf{7}$ & $\mathbf{8}$ \\
\hline Total & 1 & 8 & 19 & 5 \\
Resp (Clin) & 1 & 7 & 14 & 1 \\
Non-R (Clin) & 0 & 1 & 5 & 4 \\
Resp (Path) & 0 & 6 & 8 & 2 \\
Non-R (Path) & 1 & 2 & 11 & 3
\end{tabular}

(B) Change in immunohistochemical score with tamoxifen treatment $^{\mathrm{b}}$

\begin{tabular}{lccc} 
& Decrease & No change & Increase \\
\hline Total & 8 & 8 & 17 \\
Resp (Clin) & 5 & 4 & 14 \\
Non-R (Clin) & 3 & 4 & 3 \\
Resp (Path) & 4 & 5 & 7 \\
Non-R (Path) & 4 & 3 & 10
\end{tabular}

${ }^{a}$ Significant difference between tumours responding and not responding clinically, $P<0.015$ by $\gamma^{2}$ test for trends. ${ }^{b}$ No significant differences between responding and not responding tumours.

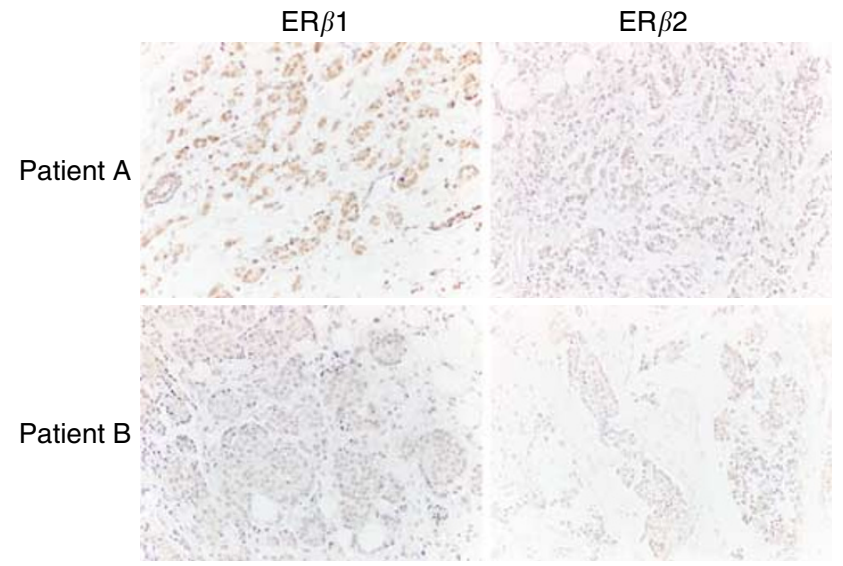

Figure I In breast cancer biopsies, $E R \beta 2 / \beta c x$ immunostatus did not parallel that of $E R \beta I$. Results from two patients before therapy are shown. Note that in patient $A$, the level of expression of $E R \beta \mid \gg E R \beta 2 / \beta c x$, whereas in patient $\mathrm{B}, \mathrm{ER} \beta \mid$ \& It $\leqslant \mathrm{ER} \beta 2 / \beta \mathrm{cx}$. Magnifications $\times 40$. 
Table 3 Oestrogen receptor $\beta 2 / \beta c \times$ (variant)

\begin{tabular}{lcccc}
$\begin{array}{l}\text { (A) Immunohistochemical score in tumours responding (Resp) and } \\
\text { not responding (Non-R) to tamoxifen } \\
\text { Score }\end{array}$ & $\mathbf{0}$ & $\mathbf{4}$ & $\mathbf{5}$ & $\mathbf{6}$ \\
\hline Total & 18 & 4 & 9 & 2 \\
Resp (Clin) & 12 & 3 & 7 & 1 \\
Non-R (Clin) & 6 & $\mid$ & 2 & $\mid$ \\
Resp (Path) & 7 & $\mid$ & 7 & $\mid$ \\
Non-R (Path) & 11 & 3 & 2 & 1
\end{tabular}

(B) Change in immunohistochemical score with tamoxifen treatment $^{\mathrm{a}}$

\begin{tabular}{lccc} 
& Decrease & No change & Increase \\
\hline Total & 11 & 16 & 6 \\
Resp (Clin) & 8 & 10 & 5 \\
Non-R (Clin) & 3 & 6 & 1 \\
Resp (Path) & 5 & 8 & 3 \\
Non-R (Path) & 6 & 8 & 3 \\
\hline
\end{tabular}

aNo significant differences between responding and non-responding tumours.

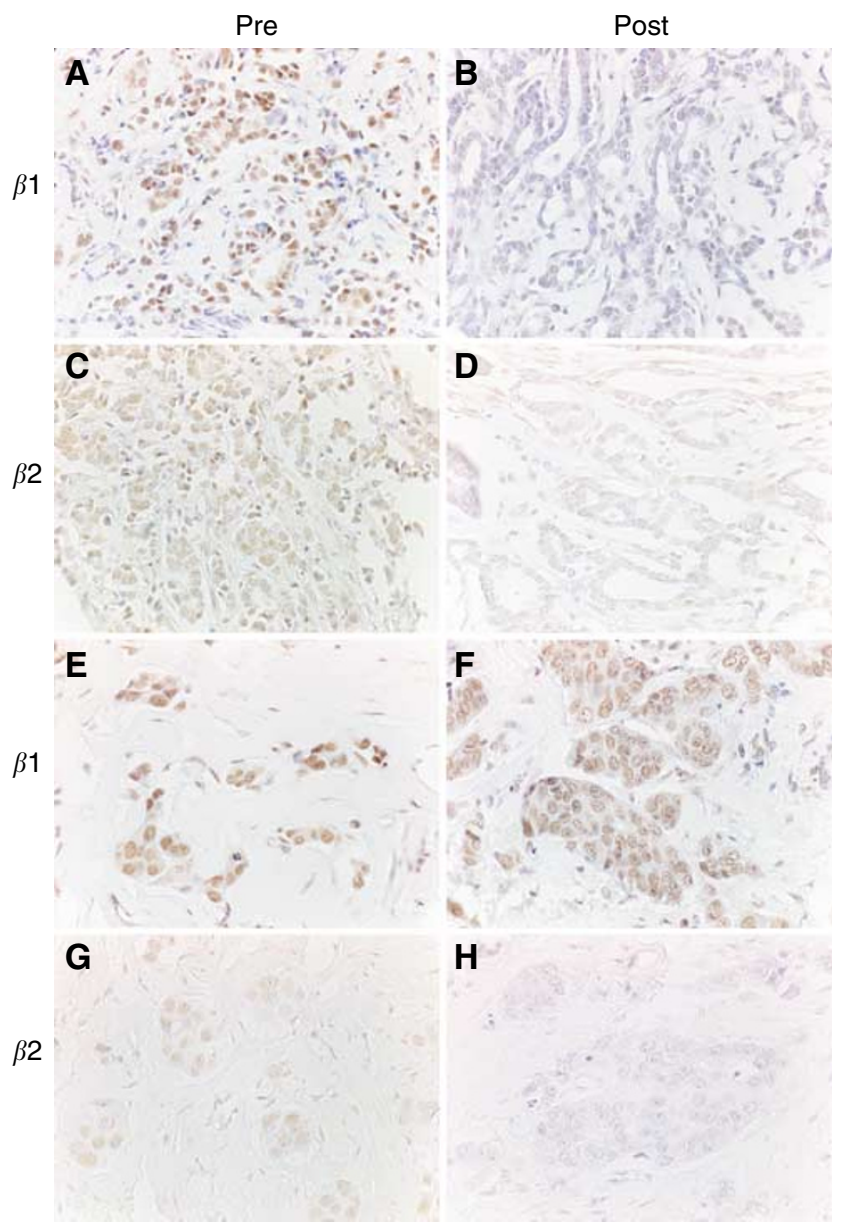

Figure 2 Immunohistochemical localisation of $E R \beta$ proteins to breast biopsies obtained before and after treatment with tamoxifen. Results for $E R \beta \mid(\mathbf{A}, \mathbf{B}, \mathbf{E}, \mathbf{F})$ and the $E R \beta 2 / \beta c x$ variant $(\mathbf{C}, \mathbf{D}, \mathbf{G}, \mathbf{H})$ are shown for two patients only one of whom $(\mathbf{A}-\mathbf{D})$ showed a positive clinical response to therapy. In both patients, ER $\beta \mid$-positive malignant cells were present before treatment $(\mathbf{A}, \mathbf{E})$, but whereas immunoexpression was reduced in the patient who responded to therapy (compare $\mathbf{A}$ and $\mathbf{B}$ ) there was no reduction in expression in the other patient who did not exhibit a clinical response (compare $\mathbf{D}$ with $\mathbf{F}$ ). In both patients, expression of $E R \beta 2 / \beta c x$ was reduced (compare $\mathbf{C}$ and $\mathbf{D} ; \mathbf{G}$ and $\mathbf{H}$ ). Magnifications, $\times 40$.

\section{DISCUSSION}

We have used well-characterised monoclonal antibodies (Critchley et al, 2002; Saunders et al, 2002a) to compare the pattern of expression of two isoforms of $\operatorname{ER} \beta$, namely the full-length functional receptor $(\operatorname{ER} \beta 1)$ and the $\operatorname{ER} \beta 2 / \beta \mathrm{cx}$ variant (Moore et al, 1998; Ogawa et al, 1998b). Oestrogen receptor $\beta 1$ contains a functional steroid binding pocket (Pike et al, 1999), an intact AF-2 domain capable of recruiting coactivators (Klinge, 2000) and is capable of inducing gene transcription in vitro (Paech et al, 1997; Barkhem et al, 1998; Sierens et al, 2004). In contrast, $\operatorname{ER} \beta 2 / \beta \mathrm{cx}$ lacks 61 amino acids normally found at the C-terminus of ER $\beta 1$ and instead contains novel 27 amino acids that do not encode a functional AF-2 domain (Ogawa et al, 1998b). Studies in vitro have shown that $\mathrm{ER} \beta 2 / \beta \mathrm{cx}$-containing constructs do not bind oestradiol and that neither can they induce gene expression via oestrogen response elements (EREs) in reporter assays (Ogawa et al, 1998b; Peng et al, 2003; Sierens et al, 2004). Interest in determining whether $\operatorname{ER} \beta 2 / \beta \mathrm{cx}$ is expressed in breast and other cancers has been fuelled by studies using transfected cells that have claimed that coexpression of $\mathrm{ER} \beta 2 / \beta \mathrm{cx}$ with $\mathrm{ER} \alpha$ results in reduced activation of ERE-containing reporter constructs (Ogawa et al, 1998b; Peng et al, 2003).

In the current study, we did not find any correlation between the intensity of immunoexpression of $\operatorname{ER} \beta 1$ and $\operatorname{ER} \beta 2 / \beta \mathrm{cx}$ in breast cancer biopsies taken before treatment, with a higher proportion of the tissues being immunopositive for $\operatorname{ER} \beta 1$ than for $\operatorname{ER} \beta 2 / \beta \mathrm{cx}$. This finding was unexpected as both the proteins are encoded by the same gene and are identical in sequence apart from alternative splicing of alternative eighth exons. We have previously noted differences in the pattern of expression of $\operatorname{ER} \beta 1$ and $\operatorname{ER} \beta 2 / \beta \mathrm{cx}$ in non-malignant tissues including the testis and endometrium (Critchley et al, 2002; Saunders et al, 2002a) and therefore do not believe that this finding is associated with the development of malignancy although it does raise questions as to the mechanisms controlling splicing of the human $\operatorname{ER} \beta$ gene. We detected ER $\beta 2 /$ $\beta \mathrm{cx}$ protein in $45 \%$ of the tumours. In other studies in which expression of $\mathrm{ER} \beta 2 / \beta \mathrm{cx}$ has been assessed using different $\mathrm{ER} \beta 2 /$ $\beta$ cx-specific antibodies, the protein has been detected in $48 \%$ (Saji et al, 2002b; Palmieri et al, 2004) or 56\% (Omoto et al, 2002) of the tissues examined, which is in general agreement with our own findings. Comparison with other studies that have reported the incidence of $\operatorname{ER} \beta$ immunostaining is not possible because they used antibodies that would not discriminate between ER $\beta 1$ and $\operatorname{ER} \beta 2 / \beta \mathrm{cx}$ variants (Jarvinen et al, 2000; Skliris et al, 2001).

Functional studies have previously claimed that the agonist activity of tamoxifen was ER $\alpha$ dependent (Watanabe et al, 1997). However, a recent study in which the conformations adopted by $\operatorname{ER} \alpha$ and $\operatorname{ER} \beta$ following binding to tamoxifen were investigated has resulted in a revised model for binding that includes interactions with both $\mathrm{ER} \alpha$ and $\operatorname{ER} \beta$ (Heldring et al, 2004). It is notable that in the current study, tamoxifen treatment had an apparent impact on the levels of expression of both $\operatorname{ER} \alpha$ and $\operatorname{ER} \beta$, but that the effects were opposite to each other, with levels of $\mathrm{ER} \alpha$ declining and those of ER $\beta 1$ increasing.

These cell-based studies provide a rationale for considering whether the expression of $\mathrm{ER} \beta 1$ and/or $\mathrm{ER} \beta 2 / \beta \mathrm{cx}$ in malignant cells within the breast can influence the response of the tissue to therapy with tamoxifen. Although there is a general consensus that the presence of $\mathrm{ER} \alpha$ predicts response to tamoxifen (ER $\alpha$-negative tumours rarely respond), the literature relating to $\operatorname{ER} \beta$ and response to tamoxifen is confusing and conflicting. In part, this is because studies have been performed in two different settings, giving tamoxifen either as an adjuvant to surgery and measuring recurrence rates/times (Murphy et al, 2002; Davies et al, 2004; Esslimani-Sahla et al, 2004; Hopp et al, 2004; O’Neill et al, 2004) or as neoadjuvant treatment and monitoring changes in the size of the primary tumours. In general, the latter studies are more 
applicable to tumour sensitivity to therapy, as recurrence in the adjuvant setting is determined not only by response to systemic treatment but also by the extent of micrometastatic disease and inherent aggressiveness of the tumour. In this respect, the most substantive neoadjuvant studies to date examining effects of the closely related anti-oestrogen, toremifene, in 38 cases of preoperatively and 20 cases of postoperatively indicated that, as in the present study, response was independent of $\operatorname{ER} \beta$ levels or changes (Cappelletti et al, 2004). Two other studies have investigated ER $\beta 2 /$ $\beta \mathrm{cx}$. One reported 23 patients who were treated neoadjuvantly and found a statistically significant association between the presence of $\mathrm{ER} \beta 2 / \beta \mathrm{cx}$ and response to tamoxifen $(P=0.04)$ but the group was unusual in that all three ER $\alpha$-negative tumours also responded to treatment. The other study (Saji et al, 2002b) evaluated 18 cases and found $\operatorname{ER} \beta 2 / \beta \mathrm{cx}$ expression to be associated with less chance of response to tamoxifen. Given that the present study failed to find either a positive or a negative association between $\mathrm{ER} \beta 2 / \beta \mathrm{cx}$ and response to tamoxifen, it seems unlikely that $\mathrm{ER} \beta 2 / \beta \mathrm{cx}$ will be predictive of response in individual cases.

In the current study, although ER $\beta 1$ protein was detected in all tumours, there was no correlation between the levels in those that responded to treatment and those that did not. Furthermore, there was no difference in the status/level of expression of $\mathrm{ER} \beta 2 / \beta \mathrm{cx}$ between tumours responding to and those that did not to tamoxifen. In conclusion, to date, there is as yet no consensus among the different studies in which response to tamoxifen has been correlated with expression of $\operatorname{ER} \beta$ and/or the $\operatorname{ER} \beta 2 / \beta \mathrm{cx}$ variant as to whether measuring $\operatorname{ER} \beta$ expression in $\operatorname{ER} \alpha$-positive breast cancers is likely to be informative as regards response to anti-oestrogen therapy.

\section{REFERENCES}

Allred DC, Harvey JM, Berardo M, Clark GM (1998) Prognostic and predictive factors in breast cancer by immunohistochemical analysis. Mod Pathol 11: 155-168

Barkhem T, Carlsson B, Nilsson Y, Enmark E, Gustafsson J, Nilsson S (1998) Differential response of estrogen receptor alpha and estrogen receptor beta to partial estrogen agonists/antagonists. Mol Pharmacol 54: $105-112$

Cappelletti V, Celio L, Bajetta E, Allevi A, Longarini R, Miodini P, Villa R, Fabbri A, Mariani L, Giovanazzi R, Galante E, Greco M, Grazia Daidone M (2004) Prospective evaluation of estrogen receptor-beta in predicting response to neoadjuvant antiestrogen therapy in elderly breast cancer patients. Endocr Relat Cancer 11: 761-770

Carder PJ, Murphy CE, Dervan P, Kennedy M, McCann A, Saunders PT, Shaaban AM, Foster CS, Witton CJ, Bartlett JM, Walker RA, Speirs V (2005) A multi-centre investigation towards reaching a consensus on the immunohistochemical detection of ERbeta in archival formalin-fixed paraffin embedded human breast tissue. Breast Cancer Res Treat 92: $287-293$

Critchley HO, Henderson TA, Kelly RW, Scobie GS, Evans LR, Groome NP, Saunders PT (2002) Wild-type estrogen receptor (ERbeta1) and the splice variant (ERbetacx/beta2) are both expressed within the human endometrium throughout the normal menstrual cycle. J Clin Endocrinol Metab 87: $5265-5273$

Davies MP, O'Neill PA, Innes H, Sibson DR, Prime W, Holcombe C, Foster CS (2004) Correlation of mRNA for oestrogen receptor beta splice variants ERI\{betal\}1, ERI\{betal\}2/ER $\backslash\{$ betal $\} \mathrm{Cx}$ and ERI\{betal\}5 with outcome in endocrine-treated breast cance. J Mol Endocrinol 33: 773-782

Esslimani-Sahla M, Simony-Lafontaine J, Kramar A, Lavaill R, Mollevi C, Warner M, Gustafsson JA, Rochefort H (2004) Estrogen receptor beta (ER beta) level but not its ER beta cx variant helps to predict tamoxifen resistance in breast cancer. Clin Cancer Res 10: 5769-5776

Forouhi P, Walsh JS, Anderson J, Chetty U (1994) Ultrasonography as a method of measuring breast tumour size and monitoring response to primary systemic treatment. Br J Surg 81: 223-225

Fuqua SA, Schiff R, Parra I, Friedrichs WE, Su JL, McKee DD, Slentz-Kesler K, Moore LB, Willson TM, Moore JT (1999) Expression of wild-type estrogen receptor beta and variant isoforms in human breast cancer. Cancer Res 59: $5425-5428$

Gaskell TL, Robinson LL, Groome NP, Anderson RA, Saunders PT (2003) Differential expression of two estrogen receptor beta isoforms in the human fetal testis during the second trimester of pregnancy. J Clin Endocrinol Metab 88: $424-432$

Hall JM, McDonnell DP (1999) The estrogen receptor beta-isoform (ERbeta) of the human estrogen receptor modulates ERalpha transcriptional activity and is a key regulator of the cellular response to estrogens and antiestrogens. Endocrinology 140: 5566-5578

Heldring N, Nilsson M, Buehrer B, Treuter E, Gustafsson JA (2004) Identification of tamoxifen-induced coregulator interaction surfaces within the ligand-binding domain of estrogen receptors. Mol Cell Biol 24: $3445-3459$

Hopp TA, Weiss HL, Parra IS, Cui Y, Osborne CK, Fuqua SA (2004) Low levels of estrogen receptor beta protein predict resistance to tamoxifen therapy in breast cancer. Clin Cancer Res 10: 7490-7499
Inoue S, Ogawa S, Horie K, Hoshino S, Goto W, Hosoi T, Tsutsumi O, Muramatsu M, Ouchi Y (2000) An estrogen receptor beta isoform that lacks exon 5 has dominant negative activity on both ERalpha and ERbeta. Biochem Biophys Res Commun 279: 814-819

Jarvinen TA, Pelto-Huikko M, Holli K, Isola J (2000) Estrogen receptor beta is coexpressed with ERalpha and PR and associated with nodal status, grade, and proliferation rate in breast cancer. Am J Pathol 156: 29-35

Klinge CM (2000) Estrogen receptor interaction with co-activators and corepressors. Steroids 65: $227-251$

Kuiper GG, Enmark E, Pelto-Huikko M, Nilsson S, Gustafsson JA (1996) Cloning of a novel receptor expressed in rat prostate and ovary. Proc Natl Acad Sci USA 93: 5925-5930

Leake R, Barnes D, Pinder S, Ellis I, Anderson L, Anderson T, Adamson R, Rhodes T, Miller K, Walker R (2000) Immunohistochemical detection of steroid receptors in breast cancer: a working protocol. J Clin Pathol 53: $634-635$

Lindberg MK, Moverare S, Skrtic S, Gao H, Dahlman-Wright K, Gustafsson JA, Ohlsson C (2003) Estrogen receptor (ER)-beta reduces ERalpharegulated gene transcription, supporting a 'Ying Yang' relationship between ERalpha and ERbeta in mice. Mol Endocrinol 17: 203-208

Miller WR (1996) Prediction of estrogen sensitivity/dependence. In Estrogen and Breast Cancer, Millar MR (ed) pp 151-169. Austin: RG Landes Co

Miller WR, Anderson TJ, Hawkins RA, Keen J, Dixon JM (1999) Neoadjuvant endocrine treatment: the Edinburgh experience. In Primary Medical Therapy for Breast Cancer: Clinical and Biological Aspects, ESO Scientific Updates, Dowsett M, Howell A (eds) Vol. 4, pp 89-99. Amsterdam: Elsevier

Moore JT, McKee DD, Slentz-Kesler K, Moore LB, Jones SA, Horne EL, Su JL, Kliewer SA, Lehmann JM, Willson TM (1998) Cloning and characterization of human estrogen receptor beta isoforms. Biochem Biophys Res Commun 247: 75-78

Mosselman S, Polman J, Dijkema R (1996) ERbeta: identification and characterization of a novel human estrogen receptor. FEBS Lett 392: 4953

Murphy LC, Leygue E, Niu Y, Snell L, Ho SM, Watson PH (2002) Relationship of coregulator and oestrogen receptor isoform expression to de novo tamoxifen resistance in human breast cancer. $\mathrm{Br}$ J Cancer 87: $1411-1416$

O'Neill PA, Davies MP, Shaaban AM, Innes H, Torevell A, Sibson DR, Foster CS (2004) Wild-type oestrogen receptor beta (ERbeta1) mRNA and protein expression in Tamoxifen-treated post-menopausal breast cancers. Br I Cancer 91: 1694-1702

Ogawa S, Inoue S, Watanabe T, Hiroi H, Orimo A, Hosoi T, Ouchi Y, Muramatsu M (1998a) The complete primary structure of human estrogen receptor beta (hER beta) and its heterodimerization with ER alpha in vivo and in vitro. Biochem Biophys Res Commun 243: 122-126

Ogawa S, Inoue S, Watanabe T, Orimo A, Hosoi T, Ouchi Y, Muramatsu M (1998b) Molecular cloning and characterization of human estrogen receptor betacx: a potential inhibitor of estrogen action in human. Nucleic Acids Res 26: 3505-3512

Omoto Y, Kobayashi S, Inoue S, Ogawa S, Toyama T, Yamashita H, Muramatsu M, Gustafsson JA, Iwase H (2002) Evaluation of oestrogen 
receptor beta wild-type and variant protein expression, and relationship with clinicopathological factors in breast cancers. Eur J Cancer 38: $380-386$

Paech K, Webb P, Kuiper GGJM, Nilsson S, Gustafsson JA, Kushner PJ, Scanlan TS (1997) Differential ligand activation of estrogen receptors ERa and ERb at AP1 sites. Science 277: 1508-1510

Palmieri C, Lam EW, Mansi J, MacDonald C, Shousha S, Madden P, Omoto Y, Sunters A, Warner M, Gustafsson JA, Coombes RC (2004) The expression of ER beta cx in human breast cancer and the relationship to endocrine therapy and survival. Clin Cancer Res 10: 2421-2428

Peng B, Lu B, Leygue E, Murphy LC (2003) Putative functional characteristics of human estrogen receptor-beta isoforms. $\mathrm{J} \mathrm{Mol}$ Endocrinol 30: 13-29

Pike AC, Brzozowski AM, Hubbard RE, Bonn T, Thorsell AG, Engstrom O, Ljunggren J, Gustafsson JA, Carlquist M (1999) Structure of the ligandbinding domain of oestrogen receptor beta in the presence of a partial agonist and a full antagonist. EMBO J 18: $4608-4618$

Poola I, Abraham J, Baldwin K (2002a) Identification of ten exon deleted ERbeta mRNAs in human ovary, breast, uterus and bone tissues: alternate splicing pattern of estrogen receptor beta mRNA is distinct from that of estrogen receptor alpha. FEBS Lett 516: 133-138

Poola I, Abraham J, Liu A (2002b) Estrogen receptor beta splice variant mRNAs are differentially altered during breast carcinogenesis. J Steroid Biochem Mol Biol 82: 169-179

Saji S, Omoto Y, Shimizu C, Horiguchi S, Watanabe T, Funata N, Hayash S, Gustafsson JA, Yoi M (2002a) Clinical impact of assay of estrogen receptor betacx in breast cancer. Breast Cancer 9: 303-307

Saji S, Omoto Y, Shimizu C, Warner M, Hayashi Y, Horiguchi S, Wantanabe T, Hayashi S, Gustafsson JA, Toi M (2002b) Expression of estrogen receptor (ER) $\beta \mathrm{cx}$ protein in ERa-positive breast cancer: specific correlation with progesterone receptor. Cancer Research 62: 4849-4853

Saunders PT, Millar MR, Macpherson S, Irvine DS, Groome NP, Evans LR, Sharpe RM, Scobie GA (2002a) ERbeta1 and the ERbeta2 splice variant (ERbetacx/beta2) are expressed in distinct cell populations in the adult human testis. J Clin Endocrinol Metab 87: 2706-2715

Saunders PT, Millar MR, Williams K, Macpherson S, Bayne C, O'Sullivan C, Anderson TJ, Groome NP, Miller WR (2002b) Expression of oestrogen receptor beta (ERbeta1) protein in human breast cancer biopsies. $\mathrm{Br} \mathrm{J}$ Cancer 86: $250-256$

Saunders PTK, Millar MR, Williams K, Macpherson S, Harkiss D, Anderson RA, Orr B, Groome NP, Scobie G, Fraser HM (2000) Differential expression of estrogen receptor-alpha and -beta and androgen receptor in the ovaries of marmosets and humans. Biol Reprod 63: 1098-1105

Sierens JE, Scobie GA, Wilson J, Saunders PT (2004) Cloning of oestrogen receptor beta from Old and New World primates: identification of splice variants and functional analysis. $J \mathrm{Mol}$ Endocrinol 32: 703-718

Skliris GP, Carder PJ, Lansdown MR, Speirs V (2001) Immunohistochemical detection of ERbeta in breast cancer: towards more detailed receptor profiling? Br J Cancer 84: 1095-1098

Speirs V, Adams IP, Walton DS, Atkin SL (2000) Identification of wild-type and exon 5 deletion variants of estrogen receptor beta in normal human mammary gland. J Clin Endocrinol Metab 85: 1601 - 1605

Speirs V, Carder PJ, Lane S, Dodwell D, Lansdown MR, Hanby AM (2004) Oestrogen receptor beta: what it means for patients with breast cancer. Lancet Oncol 5: 174-181

Strom A, Hartman J, Foster JS, Kietz S, Wimalasena J, Gustafsson JA (2004) Estrogen receptor beta inhibits 17beta-estradiol-stimulated proliferation of the breast cancer cell line T47D. Proc Natl Acad Sci USA 101: $1566-1571$

Torlakovic E, Lilleby W, Torlakovic G, Fossa SD, Chibbar R (2002) Prostate carcinoma expression of estrogen receptor-beta as detected by PPG5/10 antibody has positive association with primary Gleason grade and Gleason score. Hum Pathol 33: 646-651

Warner M, Saji S, Gustafsson JA (2000) The normal and malignant mammary gland: a fresh look with ER beta onboard. J Mammary Gland Biol Neoplasia 5: 289-294

Watanabe $\mathrm{T}$, Inoue $\mathrm{S}$, Ogawa S, Ishii $\mathrm{Y}$, Hiroi $\mathrm{H}$, Ikeda $\mathrm{K}$, Orimo $\mathrm{A}$, Muramatsu M (1997) Agonistic effect of tamoxifen is dependent upon cell type, ERE-promotor context, and estrogen receptor subtype: functional difference between estrogen receptors a and $\beta$. Biochem Biophys Res Comm 236: 140 - 145

Weihua Z, Saji S, Makinen S, Cheng G, Jensen EV, Warner M, Gustafsson JA (2000) Estrogen receptor (ER) beta, a modulator of ERalpha in the uterus. Proc Natl Acad Sci USA 97: 5936-5941 